\title{
Mirizzi syndrome grades III and IV: surgical treatment
}

\section{Síndrome de Mirizzi graus III e IV: tratamento cirúrgico}

Ronald Reverdito"; André de Moricz, TCBC-SP2; Tércio de Campos, TCBC-SP2; Adhemar Monteiro Pacheco Júnior, TCBC-SP²; Rodrigo Altenfelder Silva, TCBC-SP2.

\section{A B S T R A C T}

Objective: to evaluate the epidemiology and outcomes of surgical treatment of patients with Mirizzi Syndrome (MS) grades III and IV, the most advanced according to Csendes classification. Methods: we conducted a retrospective, cross-sectional study by reviewing records of thirteen patients with grades III and IV MS operated from December 2001 to September 2013, among the 3,691 cholecystectomies performed in the period. Results: the incidence of MS was $0.6 \%$ (23 cases) and grades III and IV amounted to $0.35 \%$ of this number. There was a predominance of type IV (12 cases). The preoperative diagnosis was possible in 53.8\% of cases. The preferred approach was biliary-digestive derivation (10 cases), and " $T$ " tube drainage with suture of the bile duct was the choice in three special occasions. Three patients had biliary fistula resolved with clinical management, and one coliperitoneum case required reoperation. In the outpatient follow-up of patients who underwent biliodigestive anastomosis (eight), 50\% are asymptomatic, 25\% had anastomotic stricture and 25\% lost follow-up. The mean follow-up was 41.8 months. Conclusion: MS in advanced degrees has low incidence, preoperative diagnosis in only half of cases, and has the biliodigestive anastomosis as the best conduct, but not without morbidity.

Keywords: Mirizzi Syndrome. Jaundice, Obstrutive. Epidemiology. Therapeutics. Surgical Procedures, Operative.

\section{INTRODUCTION}

$\mathrm{M}$ rizzi Syndrome (MS) is a rare cause of benign obstructive jaundice triggered by impacted calculus in Hartmann bag or cystic duct, causing extrinsic obstruction of the common hepatic duct. In cases of intense inflammation, it is difficult to treat. According to Csendes et al., responsible for one of its classifications, more advanced degrees include patients with cholecystobiliary fistula, with common bile duct wall erosion of two-thirds of its circumference (grade III) and complete erosion (grade IV) ${ }^{1-3}$. Subtotal cholecystectomy associated with choledocoplasty and tube " $\mathrm{T}$ " drainage or biliodigestive anastomosis are the main surgical alternatives, there being, however, no standard procedure.

This study aims to assess the epidemiology and outcomes of surgical treatment of patients with more advanced degrees of Mirizzi Syndrome (III and IV).

\section{METHODS}

We conducted a retrospective, cross-sectional study through the review of records from 13 cases oper- ated from December 2001 to September 2013 in the Department of Surgery of the Faculty of Medical Sciences of the São Paulo Holy Home (FCMSCSP) and Brotherhood of the São Paulo Holy Home (ISCMSP). We classified the cases according to Csendes et al. and selected grades III and IV. We assessed current age, gender, time of disease, diagnosis, treatment performed and postoperative outcome.

\section{RESULTS}

Of the 3,691 patients admitted for treatment of gallstones from December 2001 to September 2013, 23 (0.6\%) had MS. Disease in grades III and IV occurred in 13 patients $(0.35 \%)$, ten being women $(76.9 \%)$ and three men (23.1\%). The mean age was 55.6 years ranging from 31 to 89. Two patients had hypertension and diabetes mellitus type II. The average time of disease was 375 days, ranging from one to 60 months. Seven patients were admitted to the emergency room and six, at an outpatient basis

The most prevalent symptom was abdominal pain $(92 \%)$, followed by jaundice in $84.6 \%$; fever was present in two of the seven patients with cholangitis. Of

1 - Department of Surgery, Brotherhood of the São Paulo Holy Home, São Paulo, SP, Brazil. 2 - Biliary and Pancreas Surgery Group, Brotherhood of the São Paulo Holy Home, São Paulo, SP, Brazil. 
Table 1. Description of the stages of development of Mirizzi Syndrome and colecistobiliar fistula described by Csendes et al. (1989)2

\begin{tabular}{ll}
\hline Type I & $\begin{array}{l}\text { Extrinsic compression of the common hepatic duct by a calculus impacted in the gallbladder's infun- } \\
\text { dibulum or cystic duct. } \\
\text { Presence of cholecystobiliary fistula, with erosion of the common hepatic duct anterior or lateral }\end{array}$ \\
& $\begin{array}{l}\text { wall by an impacted calculus, where the fistula involves less than } 1 / 3 \text { of the common hepatic duct } \\
\text { circumference. }\end{array}$ \\
Type III & $\begin{array}{l}\text { Presence of cholecystobiliary fistula with hepatic duct wall erosion involving up to } 2 / 3 \text { of its circum- } \\
\text { ference. }\end{array}$ \\
Type IV & Presence of cholecystobiliary fistula with complete destruction of the common hepatic duct wall.
\end{tabular}
Source: Leopardi LN, Maddern GJ. Pablo Luis Mirizzi: the man behind the syndrome. ANZ J Surg. 2007;77(12):1062-41.

the 11 individuals with history of jaundice, $63.6 \%$ had a total bilirubin greater than $3 \mathrm{mg} / \mathrm{dl}$ in the first evaluation. At least one of the canalicular enzymes was altered in $92.3 \%$ of cases. Only one patient had both enzymes normal at admission. Alkaline phosphatase levels ranged between 142 and 1,942 U/L, and gamma glutamyl transferase, 31-2,836 U/L.

Among imaging tests, abdominal ultrasound was performed in all patients and suggested the diagnosis in $23 \%$ of cases; five patients underwent computed tomography of the abdomen, which showed the diagnosis in two cases and only one case underwent Magnetic resonance cholangiography, which was suggestive of MS. The main differential diagnosis was isolated choledocholithiasis. Endoscopic retrograde cholangiopancreatography $(\mathrm{ERCP})$ was performed preoperatively in seven cases (53.8\%) and suggested the diagnosis in $57.1 \%$ of cases. Of these, it identified choledocholithiasis in six cases, three had cholangitis and in two a prosthesis was inserted in the bile duct. All of them undergone endoscopic papillotomy.

The preoperative diagnosis was suspected in $53.8 \%$ of cases. In two situations surgery started by laparoscopy, but due to the difficulties of dissection and anatomy doubt, conversion proved the best option. The intraoperative finding was MS grade III in one case (7.7\%) and grade IV in 12 (92.3\%). Choledocholithiasis was associated in $61.5 \%$ and cholangitis in $38.4 \%$. There was one case of cholecystoduodenal fistula and one case of cholecystogastric fistula.

All patients underwent cholecystectomy and the preferred surgical approach was Roux-en-Y hepaticojejunal anastomosis, performed in nine patients (62.2\%). Tube " $T$ " drainage was used in three cases (23\%) and choledocoduodenal anastomosis in one (7.7\%). In all cases, the bile duct was explored and the abdominal cavity drained. The average operative time was 318 minutes, ranging from 180 to 420 . Three patients had to receive blood transfusion during surgery.

Local postoperative complications occurred in $53.8 \%$ of cases, the most frequent being biliary fistula (30.7\%), followed by stenosis of the biliodigestive anastomosis (15.3\%) and transpapillary bleeding (one case). Reoperation was required in one case, on the seventh day after surgery, due to choleperitoneum. This patient presented the two main complications, fistula and stenosis. Patients who developed stenosis required sessions of transparietohepatic dilatation; one presented with good results and one with secondary biliary cirrhosis due to initial treatment dropout. In patients for whom tube " $T$ " drainage was used, this remained for four to six months ${ }^{3-7}$ (Table 2).

Two patients died (15.3\%). One previously submitted to preoperative ERCP presented sudden death on the second day after surgery. The necropsy showed a not externalized papillae bleeding. The other had septic shock secondary to cholangitis on the third day after surgery.

Pathological examination showed benign disease in all cases (calculi cholecystitis, whether chronic or in an acute outbreak). The mean postoperative follow-up was 41.8 months, ranging from one to $132 ; 15.3 \%$ of patients lost follow-up and $53.8 \%$ are asymptomatic, with normal exams.

\section{DISCUSSION}

The results of this review confirm the low incidence of MS (0.6\%) in patients undergoing cholecystec- 
tomy due to gallbladder calculi disease. In the literature there is incidence of $0.05 \%$ to $2.7 \% 8,9$. The advanced cases, the object of this study, had an even lower incidence $(0.35 \%)$. Due to low frequency, the experience with this type of condition is limited and restricted to work series.

There was a predominance of women and a mean age of 55.6 years, consistent with literature values that show approximate incidence of $70 \%$ in women and aged 53-70 years ${ }^{10}$.

The main symptoms of abdominal pain (92\%) and jaundice (84.6\%) were present in most cases, associated with a long mean time of disease, more than one year. In the literature, the most common clinical presentation includes obstructive jaundice (60\% to $100 \%$ ) accompanied by abdominal right upper quadrant pain $(50 \%$ to $100 \%)$, and fever $r^{1,2,6-14}$.

Canalicular enzymes were altered in $92.3 \%$ of tests; bilirubin was above $3 \mathrm{mg} / \mathrm{dl}$ in $53.8 \%$. Hyperbilirubinemia is common, and alkaline phosphatase and gamma GT levels may be high according to other researchers ${ }^{1,2,8-10}$. Leukocytosis can be seen associated with complications such as acute cholecystitis, cholangitis and acute pancreatitis ${ }^{8}$. Elevated levels of CA 19.9 have been found in patients with MS grade II or higher 8,15 .

Preoperative diagnosis is ideal, but not always done. The incidence of intraoperative bile duct injury in previously undiagnosed cases may be more than $17 \%$. In our sample, preoperative diagnosis was made in 53\% of cases. Abdominal ultrasound, done in all cases, suggested diagnosis in only $23 \%$ of the time. Computed tomography, magnetic resonance cholangiography and endoscopic retrograde cholangiopancreatography (ERCP) complemented the diagnostic armamentarium.

The accuracy of abdominal ultrasound in MS is $29 \%$ and the sensitivity varies from $8.3 \%$ to $27 \%{ }^{6,8}$. The CT scan is not specific, but can exclude neoplastic lesions $5^{6,7,9-13}$. Magnetic resonance cholangiography has an accuracy of $50 \%$ and ERCP is the most sensitive imaging modality, with $50 \%$ to $100 \%$, and can be therapeutic through biliary calculi extraction and insertion of prosthesis ${ }^{8}$.

Surgery began laparoscopically twice and on both occasions, the intense inflammatory process prompted conversion. Work on laparoscopic cholecystectomy in MS show high levels of conversion (31\% to 100\%), complication rates of zero to $60 \%$, biliary damage rates of zero to $22 \%$, and mortality ranging from zero to $25 \%{ }^{10}$. With the technical advances, new materials and greater surgeon experience, this modality may become more secure. However, the conventional approach is still the gold standard ${ }^{6-14}$.

Considering MS with biliary fistula of more than a third of choledocus diameter, the cases studied comprise on grade III case $(7.7 \%)$ and 12 grade IV cases $(92.3 \%)$ of the 23 MS cases diagnosed in the period, differing from most work in which the lower grades predominate ${ }^{6-14}$.

In fact, this aspect reflects the delay in the treatment of patients with cholelithiasis, most often with a long disease time and the difficulty of access to health services.

Table 2. Results of the surgical management of Mirizzi Syndrome.

\begin{tabular}{|c|c|c|c|c|c|c|c|c|}
\hline Study & $n$ & $\begin{array}{l}\text { Type } \\
\mid / \| \\
\end{array}$ & $\begin{array}{l}\text { Type } \\
\text { III/IV }\end{array}$ & $\begin{array}{c}\text { Postoperative } \\
\text { hemorrhage }\end{array}$ & $\begin{array}{l}\text { Biliary } \\
\text { fistula }\end{array}$ & $\begin{array}{l}\text { Biliary } \\
\text { stenosis }\end{array}$ & Choleperitoneum & $\begin{array}{l}\text { Follow-up } \\
\text { time }\end{array}$ \\
\hline $\begin{array}{l}\text { Csendes et al., } \\
1989^{2}\end{array}$ & 219 & $23 / 90$ & $97 / 9$ & 4 & 16 & 12 & 6 & $\begin{array}{l}1 \text { a } 13 \\
\text { years }\end{array}$ \\
\hline $\begin{array}{l}\text { Ibrarullah et } \\
\text { al., } 1993^{3}\end{array}$ & 14 & $4 / 7$ & $3 / 0$ & 0 & 0 & 0 & 1 & $\begin{array}{l}1 \text { to } 27 \\
\text { months }\end{array}$ \\
\hline $\begin{array}{l}\text { Xiaodong } \\
\text { et al., 19994 }\end{array}$ & 16 & $4 / 8$ & $3 / 1$ & 0 & 0 & 0 & 0 & $\begin{array}{l}78 \text { months } \\
\text { (average) }\end{array}$ \\
\hline $\begin{array}{l}\text { Johnson } \\
\text { et al., } 2001^{5}\end{array}$ & 11 & $5 / 3$ & $3 / 0$ & 1 & 0 & 1 & 2 & 1 to 20 years \\
\hline $\begin{array}{l}\text { Cui Y et al., } \\
2012^{6}\end{array}$ & 198 & $117 / 49$ & $26 / 6$ & 0 & 0 & 3 & 0 & 1 to 5 years \\
\hline
\end{tabular}

Adapted from: Lai EC, Lau WY. Mirizzi syndrome: history present and future development. Anz J Surg. 2006;76(4):251-77. 
As for the procedure performed, all patients were submitted to cholecystectomy, exploration of bile duct and cavity drainage. Surgical times were long, with an average of five hours. Choledocholithiasis was found in $61.5 \%$ of cases and cholangitis in $38.4 \%$.

The preferred therapeutic approach was RouxenY hepaticojejunal anastomosis. One case with partial gastrectomy for peptic ulcer disease underwent a choledocoduodenal anastomosis, since this segment was already excluded from intestinal transit.

When using the " $T$ " tube drainage, it remained for four to six months, aiming to shape the bile duct and prevent stenosis. This approach was adopted on three occasions associated with the suture of the biliary orifice over the drain: One patient in the second trimester of pregnancy who remained with the drain till the late postpartum period; one individual who had verticalized hepatic ducts, hampering the biliodigestive anastomosis; and one patient with cholangitis, displaying a bile duct with thickened wall and diminished lumen.

There were two cases of fistula with the digestive tract: the duodenum and stomach. Fistulas is not unusual due to the same pathophysiological mechanism, ie, intense inflammatory process, leading to adhesions between the viscera triggered by vesicular calculation.

Pathological examination showed benign disease in all cases. The association between MS and gallbladder cancer is well established. Some studies suggest the incidence of up to $5.3 \%$, but series with the largest number of patients do not bring any report of associated cancer ${ }^{6,15,16}$.

Postoperative local complications occurred in half the cases, mainly the biliary fistula (30.7\%). Usually benign, it presents resolution in a few days. Only one case required reoperation for better drainage of the cavity. Comparative data of postoperative complications of different works are shown in Table 2.

Mortality was $15.3 \%$ ( 2 cases) and was due to postoperative, not externalized transpapillary bleeding in a patient who had undergone preoperative endoscopic papillotomy and presented sudden death on the second day after surgery. The diagnosis was confirmed at autopsy. The other death was in one patient admitted with cholangitis who had multiple organ failure preoperatively.

In the outpatient follow-up of patients with biliary-enteric anastomosis (8 cases), 50\% are asymptomatic, 25\% had anastomotic stricture and 25\% were lost to follow-up early in the process. Among those who underwent drainage of the bile duct with " $T$ " tube (three cases), all remained asymptomatic after tube removal.

Being a low incidence condition and displaying preoperative diagnosis in only half of the cases, Mirizzi Syndrome is a challenge. The preferred approach in advanced cases is biliodigestive anastomosis, especially when there are fistulas wider than two-thirds of the diameter of the common hepatic duct, when both morbidity and mortality have considerable rates. Among the late complications, the stenosis of the bile duct stands out, the long-term follow-up being imperative.

\title{
R E S U M O
}

\begin{abstract}
Objetivo: avaliar a epidemiologia e os resultados do tratamento cirúrgico de doentes portadores de graus III e IV, mais avançados, da Síndrome de Mirizzi (SM) de acordo com a classificação de Csendes. Métodos: estudo retrospectivo, de corte transversal através da revisão de prontuários de 13 pacientes portadores de graus III e IV da SM operados de dezembro de 2001 a setembro de 2013, entre 3691 colecistectomias realizadas neste período. Resultados: a incidência da SM foi 0,6\% (23 casos) e os graus III e IV perfizeram 0,35\% deste número. Houve um predomínio de tipo IV (12 casos). O diagnóstico pré-operatório foi possível em 53,8\% dos casos. A conduta preferencial foi derivação biliodigestiva (10 casos) e foi optado por drenagem com tubo " $T$ " e sutura da via biliar em três ocasiões especiais. Três pacientes apresentaram fístula biliar resolvida com conduta expectante e um caso de coleperitônio necessitou reoperação. No seguimento ambulatorial dos pacientes que realizaram a anastomose biliodigestiva (oito), 50\% estão assintomáticos, 25\% apresentaram estenose da anastomose e $25 \%$ perderam seguimento. O tempo médio de acompanhamento foi 41,8 meses. Conclusão: de incidência baixa e de diagnóstico pré-operatório em apenas metade dos casos, a SM em graus avançados tem na anastomose biliodigestiva sua melhor conduta, porém não isenta de morbimortalidade.
\end{abstract}

Descritores: Síndrome de Mirizzi. Icterícia Obstrutiva. Epidemiologia. Terapêutica. Procedimentos Cirúrgicos Operatórios. 


\section{REFERENCES}

1. Leopardi LN, Maddern GJ. Pablo Luis Mirizzi: the man behind the syndrome. ANZ J Surg. 2007;77(12):1062-4.

2. Csendes A, Diaz JC, Burdlies P, Maluenda F, Nava O. Mirizzi syndrome and cholecystobiliary fistula: a unifying classification. Br J Surg. 1989;76(11):1139-43.

3. Ibrarullah M, Saxena R, Sikora SS, Kapoor VK, Saraswat VA, Kaushik SP. Mirizzi's syndrome: identification and management strategy. Aust N Z J Surg. 1993;63(10):802-6.

4. Xiaodong H, Hongsheng L, Chaoji Z, Zhenhuan Z, Jianxi Z. Diagnosis and treatment of the Mirizzi syndrome. Chin Med Sci J. 1999;14(4):246-8.

5. Johnson LW, Sehon JK, Lee WC, Zibari GB, McDonald JC. Mirizzi's syndrome: experience from a multi-institucional review. Am Surg. 2001; 67(1):11-4.

6. Cui Y, Liu Y, Li Z, Zhao E, Zhang H, Cui N. Appraisal of diagnosis and surgical approach for Mirizzi syndrome. ANZ J Surg. 2012;82(10):708-13.

7. Lai EC, Lau WY. Mirizzi syndrome: history, present and future development. ANZ J Surg. 2006;76(4):251-7.

8. Erben $Y$, Benavente-Chenhalls LA, Donohue JM, Que FG, Kendrick ML, Reid-Lombardo KM, et al. Diagnosis and treatment of Mirizzi syndrome: 23-year Mayo Clinic experience. J Am Coll Surg. 2011;213(1):114-9.

9. Waisberg J, Corona A, de Abreu IW, Farah JF, Lupinacci RA, Goffi FS. Benign obstruction of the common hepatic duct (Mirizzi syndrome): diagnosis and operative management. Arq Gastroenterol. 2005;42(1):13-8.

10. Beltrán MA. Mirizzi syndrome: history, current knowledge and proposal of a simplified classifica- tion. World J Gastroenterol. 2012;18(34):4639-50.

11. Al-Akeely MH, Alam MK, Bismar HA, Khalid K, AlTeimi I, Al-Dossary NF. Mirizzi syndrome: ten years experience from a teaching hospital in Riyadh. World J Surg. 2005;29(12):1687-92.

12. Karademir S, Astarcio lu H, Sökmen S, Atila K, Tankurt E, Akpinar $H$, et al. Mirizzi's syndrome: diagnostic and surgical considerations in 25 patients. J Hepatobiliary Pancreat Surg. 2000;7(1):72-7.

13. Wichmann C, Wildi S, Clavien PA. The relationship of Mirizzi syndrome and cholecystoenteric fistula: validation of a modified classification. World J Surg. 2008;32(10):2244-5.

14. Shah OJ, Dar MA, Wani MA, Wani NA. Management of Mirizzi syndrome: a new surgical approach. ANZ J Surg. 2001;71(7):423-7.

15. Redaelli CA, Büchler MW, Schilling MK, Krähenbühl $L$, Ruchti C, Blumgart LH, et al. High coincidence of Mirizzi syndrome and gallblandder carcinoma. Surgery. 1997;121(1):58-63.

16. Prasad TL, Kumar A, Sikora SS, Saxena R, Kapoor VK. Mirizzi syndrome and gallbladder cancer. J Hepatobiliary Pancreat Surg. 2006;13(4):323-6.

Received in: 24/02/2016

Accepted for publication: 06/06/2016

Conflict of interest: none.

Source of funding: none.

\section{Mailing address:}

Ronaldo Reverdito

E-mail: r_reverdito@hotmail.com 